\title{
Risk factors associated with the occurrence of Cryptosporidium parvum infection in calves
}

[Fatores de risco associados à ocorrência de infecção por Cryptosporidium parvum em bezerros]

\author{
A.J. Almeida ${ }^{1}$, F.C.R. Oliveira ${ }^{1}$, V.M.Q. Flores ${ }^{2}$, C.W.G. Lopes ${ }^{3}$ \\ ${ }^{1}$ Laboratório de Sanidade Animal - UENF \\ Av. Alberto Lamego, 2000 \\ 28013-600 - Campos dos Goytacazes, RJ \\ ${ }^{2}$ Núcleo de Análise Genômica - UENF \\ ${ }^{3}$ Departamento de Biologia Animal - IB-UFRRJ - Seropédica, RJ
}

\begin{abstract}
Cryptosporidium parvum oocysts were detected in feces of dairy calves raised in Rio de Janeiro State and the risk factors involved in the infection were determined. A hundred calves aging up to 12-month-old from 13 dairy farms were sampled. Polymerase chain reaction was used to detect the presence of oocysts. The zoonotic $C$. parvum species was detected in $45 \%$ animals. Statistical risk factors analyses revealed an association between infection and animals raised in technical systems such as the use of milking equipment, milking cooler, and water trough $(\mathrm{P}<0.05)$.
\end{abstract}

Keywords: dairy calf, criptosporidiosis, protozoan, risk factors

\section{RESUMO}

Detectaram-se oocistos de Cryptosporidium parvum em fezes de bezerros leiteiros no estado do Rio de Janeiro e analisaram-se os fatores de risco envolvidos na infecção dos animais. Cem bezerros com idades de 0 a 12 meses, provenientes de 13 propriedades rurais, foram amostrados, e suas fezes examinadas pela reação em cadeia da polimerase para a detecção dos oocistos. A espécie zoonótica C. parvum foi detectada em $45 \%$ dos animais. As análises estatísticas dos fatores de risco revelaram haver associação entre infeç̧ão e animais criados em propriedades tecnificadas, que usam ordenha mecanizada, resfriamento de leite e fazendas que continham reservatórios de água à disposição dos animais $(P<0,05)$.

Palavras-chave: bovino, criptosporidiose, protozoário, fatores de risco

\section{INTRODUCTION}

Protozoan from the genus Cryptosporidium causes diarrhea in a wide range of vertebrates including humans (Current et al., 1983). Although they have been reported in people from three days to 95 years old, the highest infection prevalence has been recognized in both children and young animals, and they are reported as a major cause of self-limiting diarrhea in immunocompetent people (Fayer et al., 1990; Chen et al., 2002). C. parvum is a particularly

Recebido em 11 de maio de 2010

Aceito em 27 de dezembro de 2010

E-mail: jardim@uenf.br

Suporte financeiro: FAPERJ serious health threat to immunodeficient individuals, having no effective treatments for the disease (Kuczynska and Shelton 1999). Cryptosporidium oocysts have been reported to cause several water-borne and food-borne outbreaks worldwide (Smith and Rose, 1998; Fayer et al., 2000), and are resistant to disinfectants commonly used in drinking water treatment, consequently, the detection of oocysts is important to the water industry (Xiao et al., 2000; Liao et al., 2001). Most human infections are due to C. parvum (Ramirez et al., 2004), and fecal food and drink contamination as well as 
person-to-person contact with oocysts are the most common methods of enteric protozoan transmission (Laubach et al., 2004).

The prevalence of $C$. parvum infection in animals is high (Villacorta et al., 1991; Ederli et al., 2004; Almeida et al., 2008). Dairy and beef calves are generally considered as presenting the highest risk because of their numbers, distribution, high infection occurrence, and high oocyst excretion levels (Kuczynska and Shelton, 1999), besides be exposed to contamination environment sources, such as soil and water.

Taking into account the high prevalence of $C$. parvum infection in calves and humans, and the lack of researches involving risk factors for this protozoan in Brazil, the objective of this work was not only to discuss the occurrence of this parasite, but also to detect the risk factors for contamination in different breeding systems.

\section{MATERIAL AND METHODS}

The study was carried out in 13 farms located at the North of Rio de Janeiro State, Brazil. Faecal samples from 100 calves (50 males and 50 females), aging up to 12-months-old, were collected, regardless symptoms of diarrhea.

Data were collected from a questionnaire on factors hypothesized to be associated with the risk of $C$. parvum infection in calves, such as farm size, water source, animal gender, flooring type, management, and different breeding systems.

To clean Cryptosporidium oocysts, $15 \mathrm{~g}$ of feces were suspended (vortex) in $35 \mathrm{~mL}$ of deionized water, then filtered through a 325-mesh wire screen. After centrifugation at $2500 \mathrm{~g}$ for $10 \mathrm{~min}$, the pellet was resuspended in deionized water to a final volume of $25 \mathrm{~mL}$ and an additional $25 \mathrm{~mL}$ sucrose solution $\left(1.1 \mathrm{~g} / \mathrm{cm}^{3}\right)$ was added. The material was thoroughly mixed, and centrifuged at $250 \mathrm{~g}$ for $20 \mathrm{~min}$. Four milliliters of supernatant were aspirated from the top, pipetted into a conical tube, then deionized water was added to the solution to reach a final volume of $15 \mathrm{~mL}$. The suspension was centrifuged at $2500 \mathrm{~g}$ for $10 \mathrm{~min}$, and the pellet was resuspended in $500 \mu \mathrm{L}$ deionized water, being the final solution stored at $-20^{\circ} \mathrm{C}$.
For the DNA extraction, $50 \mu \mathrm{L}$ of the concentrated material were placed in $1.5 \mathrm{~mL}$ microcentrifuge tube containing $0.5 \mathrm{~mL}$ of DNA extraction buffer (Tris $50 \mathrm{mM}, \mathrm{NaCl} 100 \mathrm{mM}$, EDTA $0,05 \mathrm{mM}$ ). Proteinase $\mathrm{K}$ and SDS were added to final concentrations of $1.7 \mathrm{mg} / \mathrm{mL}$ and $2.5 \%$, respectively, and they were added to the mixture. The samples were stored at $55^{\circ} \mathrm{C}$ overnight in stirred water bath. After these steps, $700 \mu \mathrm{L}$ TE-saturated phenol-chloroform were placed into each tube, and after manual water agitation at room temperature, samples were centrifuged at $12000 \mathrm{~g}$ for $10 \mathrm{~min}$. The upper aqueous phase was collected and transferred to another $1.5 \mathrm{~mL}$ microcentrifugue tube, and DNA was precipitated with sodium acetate and isopropanol. The tubes were stored on ice for 15 minutes, then centrifuged at $12000 \mathrm{~g}$ during $20 \mathrm{~min}$. The supernatant was discarded, $1 \mathrm{~mL}$ cold ethanol $70 \%$ was added, and after inverting the tubes, the samples were centrifuged at $12000 \mathrm{~g}$ for $5 \mathrm{~min}$. The tubes were inverted on a paper wipe for a few minutes and dried completely at $38^{\circ} \mathrm{C}$. Finally, the DNA extracted was suspended in $50 \mu \mathrm{L}$ ultra pure water.

Polymerase chain reaction amplification was performed in $20 \mu \mathrm{L}$ total volume and included $2 \mu \mathrm{L}$ extracted DNA. For the $18 \mathrm{~S}$ rRNA reaction, the following concentrations of the various reagents were used: $1 \times \mathrm{xCR}$ buffer, $3 \mathrm{mM} \mathrm{MgCl}_{2}$, 0,2mM each dNTP, 1.5 units Taq DNA polymerase, and 50pmol each forward and reverse primers. For the Nested PCR (secondary amplification), the following concentrations of reagents were used: 1xPCR buffer, $1.5 \mathrm{mM}$ $\mathrm{MgCl}_{2}, 0.2 \mathrm{mM}$ each dNTP, 1.5 units Taq polymerase, and 50pmol each forward and reverse primers. The primers sequences used in the reactions were: CryptoF: 5' TTC TAG AGC TAA TAC ATG CG 3' and CryptoR: 5' CCC TAA TCC TTC GAA ACA GGA 3' (primary amplification) and AL1598: 5' AAG GAG TAA GGA ACA ACC TCC A 3' and AL3032: 5' GGA AGG GTT GTA TTT ATT AGA TAA AG 3' (Nested PCR). For primary amplification, reaction mixtures were denatured at $94^{\circ} \mathrm{C}$ for $3 \mathrm{~min}$, then subjected to 35 cycles of $45 \mathrm{~s}$ at $94^{\circ} \mathrm{C}$, $45 \mathrm{~s}$ at $59^{\circ} \mathrm{C}$, and $60 \mathrm{~s}$ at $72^{\circ} \mathrm{C}$, and a final $7 \mathrm{~min}$ extension at $72^{\circ} \mathrm{C}$. The Nested PCR was performed at $94^{\circ} \mathrm{C}$ for $1 \mathrm{~min}$, then subjected to 40 cycles of $30 \mathrm{~s}$ at $94^{\circ} \mathrm{C}, 90 \mathrm{~s}$ at $58^{\circ} \mathrm{C}$, and $2 \mathrm{~min}$ at $72^{\circ} \mathrm{C}$, and a final $7 \mathrm{~min}$ extension at $75^{\circ} \mathrm{C}$. The PCR products were analyzed by electrophoresis 
on horizontal agarose gels (2\%) in TAE buffer (40mM Tris acetate, $2 \mathrm{mM} \mathrm{Na} \mathrm{NaDTA}_{2}$ ), stained with ethidium bromide and visualized under a UV transilluminator.

Comparisond of infection occurrence rates among the groups were made by the Chi-square statistic test or the Fisher Exact Test with Yates correction and 95\% confidence interval. Among groups, differences were tested for significance at the $5 \%$ level of probability $(\mathrm{P}<0.05)$.

\section{RESULTS}

The number of samples collected from each farm ranged from one to 11, with an average of five samples per farm. DNA fragments of the expected size were obtained in 45 samples (45\%) from 11 out of the $13(84.6 \%)$ examined farms (Table 1).

Table 1. Results of polymerase chain reaction for Cryptosporidium parvum in dairy calves according to the farms

\begin{tabular}{|c|c|c|c|}
\hline \multirow{2}{*}{ Farm } & \multicolumn{2}{|c|}{ Samples } & \multirow{2}{*}{$\%$} \\
\hline & Number of calves examined & Positive & \\
\hline 1 & 7 & & 0 \\
\hline 2 & 1 & 1 & 100 \\
\hline 3 & 11 & 4 & 36.4 \\
\hline 4 & 7 & 4 & 57.1 \\
\hline 5 & 7 & & 0 \\
\hline 6 & 9 & 3 & 33.3 \\
\hline 7 & 6 & 4 & 66.7 \\
\hline 8 & 8 & 7 & 87.5 \\
\hline 9 & 9 & 3 & 33.3 \\
\hline 1 & 7 & 1 & 14.3 \\
\hline 11 & 8 & 4 & 50 \\
\hline 12 & 9 & 9 & 100 \\
\hline 13 & 11 & 5 & 45.5 \\
\hline Total & 100 & 45 & 45.0 \\
\hline
\end{tabular}

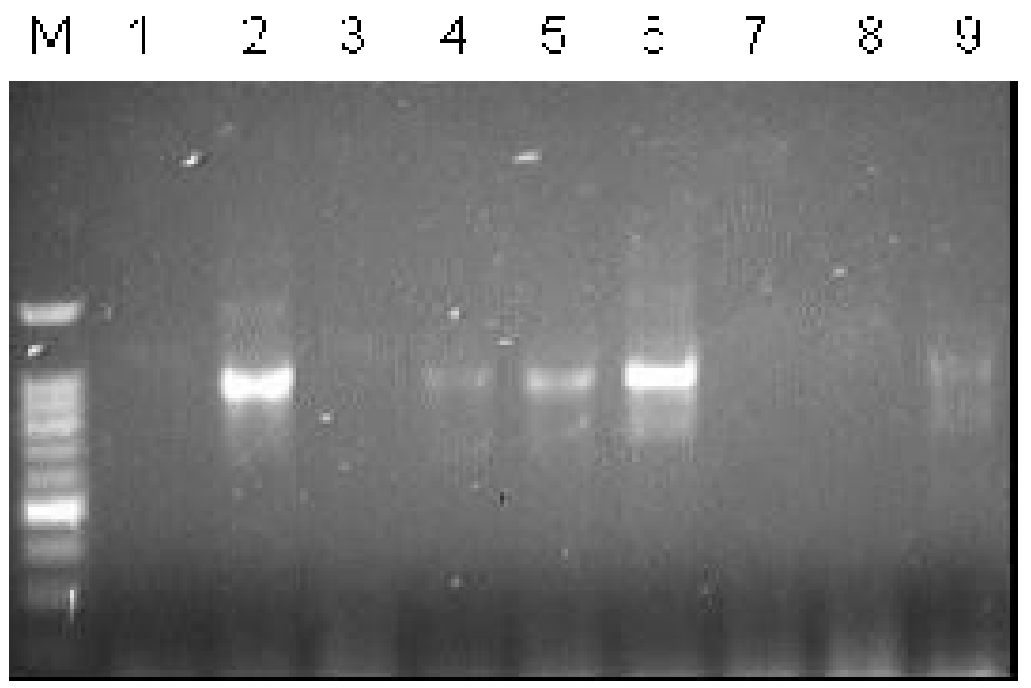

Figure 1. Detection of Cryptosporidium parvum in feces by polymerase chain reaction. M: 100bp ladder of molecular weight marker. Lane 1; negative control. Lanes 2, 4, 5, 6, and 9; positive samples. Lanes 3, 7, and 8; negative samples. 
Several factors were not associated with the shedding of C. parvum. The farm size (up to 100 and more than 100 hectares) did not have any significant effect on the risk of infection by $C$. parvum ( $\mathrm{P}=0.06$; $\mathrm{Rr}=0.70$ : $0.49-0.99)$; as well as the water source, whether from waterfalls or lakes or rivers $(\mathrm{P}=0.27 ; \mathrm{Rr}=1.13$ : $1.37-0.84)$; the flooring type, whether made of wood or concrete $(\mathrm{P}=0.23 ; \quad \mathrm{Rr}=1.22$ : 0.92-1.61); and hygiene conditions, being considered good or bad, according to the observations $(\mathrm{P}=0.33$; $\mathrm{Rr}=0.75$ : 0.46-1.21).
On the other hand, some other factors were significantly associated with the risk of $C$. parvum infection. The use of milking equipment was one of the considered risk factors, and results showed significant differences in the prevalence of cryptosporidiosis in farms having or not milking equipment. Other variables studied, such as the presence of a milking cooler and water trough were both shown as having significant influence for the $C$. parvum infection in the studied farms. The statistic analyses of these variables are showed in Table 2.

Table 2. Relative risk of Cryptosporidium parvum infection in calves

\begin{tabular}{|c|c|c|c|c|}
\hline \multicolumn{2}{|c|}{ Variable } & Positive & Negative & Fisher exact test \\
\hline \multirow{3}{*}{ Milking } & Hand & 16 & 40 & $\mathrm{P}<0.0001$ \\
\hline & mechanized & 26 & 09 & $\mathrm{Rr}=0.46$ \\
\hline & & & & $0.31<\mathrm{Rr}<0.70$ \\
\hline \multirow{3}{*}{ Use of milking cooler } & Yes & 25 & 09 & $\mathrm{P}<0.0001$ \\
\hline & No & 13 & 33 & $\mathrm{Rr}=3.07$ \\
\hline & & & & $1.16<\mathrm{Rr}<5.72$ \\
\hline \multirow{3}{*}{ Presence of trough } & Yes & 33 & 19 & $\mathrm{P}=0.0001$ \\
\hline & No & 09 & 30 & $\mathrm{Rr}=2.02$ \\
\hline & & & & $1.37<\mathrm{Rr}<2.98$ \\
\hline
\end{tabular}

\section{DISCUSSION}

In recent years, concern has increased regarding the potential public health hazard of water supplies contamination by C. parvum. Dairy herds are one of the potential sources of this parasite (Angus, 1991). The high percentage of positive samples (45\% of analyzed animals and $84.6 \%$ of visited farms) showed the high occurrence of the parasite and possible environmental contamination due to the infected animals. Results reported in different countries show values ranging from 13 to $100 \%$ of properties contamination and 0.9 to $61 \%$ of parasite-infected calves, with high prevalence in Brazil (Wade et al., 2000; Fayer et al., 2006; Park et al., 2006; Castro-Hermida et al., 2007; Almeida et al., 2009).

In a recent study done in São Paulo, Féres at al. (2009) observed that $38.1 \%(8 / 21)$ of properties that raised lambs had positive animals for Cryptosporidium, with an incidence of $6.7 \%$ $(31 / 460)$ in animals, having no significant difference between the breeding system and number of positive samples. Féres et al. (2009) identified a sample of $C$. parvum 18S rRNA type A, what is most common in ruminants infections, and also a strain of C. parvum $18 \mathrm{~S}$ rRNA type B, all with zoonotic potential.

Studies show that the effectiveness of Cryptosporidium oocysts recovery methods depends on the sample nature and the used methodology for oocysts concentration (Machado et al., 2009), which may explain the wide variation of results related to protozoan occurrence.

The presence of water trough was significantly associated with the relative risk of infection by C. parvum. This association can be explained by the fact that the water trough is probably potential reservoirs of Cryptosporidium, since the oocysts can survive in water for a long period of time (Simmons III et al., 2001; Luna et al., 2002) and probably there is constant fecal contamination of that water by animals and even by humans. Thus, hygiene methods to clean and disinfect water troughs should be taken into account as important preventive strategies. 
Machado et al. (2009) analyzed water from collection sites in Pernambuco and found Cryptosporidium oocysts in both raw and treated water, and reported the presence of a riverside location cattle pen close to a water collection site.

The raising of calves under technical systems was considered a factor that was statistically associated with the shedding of $C$. parvum. Interestingly, farms having milking equipments and milking coolers were more likely to have calves infected with the parasite than farms thar did not have the equipments, in accordance with observations done by Feitosa et al. (2004) and Almeida et al. (2009), in Brazil as well. This result is somewhat difficult to explain, but it might be related to the higher levels of stress and physiologic demands suffered by adult animals, being submitted to commercial breeding systems, compared to calves bred under family raising systems. Then, probably the juveniles are being contaminated by the high number of older stressed calves.

It was interesting to observe that no association was found between different hygiene conditions and the likelihood of infection with C. parvum, what is in accordance with the findings by Maldonado-Camargo et al. (1998) in Mexico and Maddox-Hyttel et al. (2006) in Denmark. Those data are worrying since they show how difficult it is to prevent parasite dissemination.

Similarly to findings by Tarazona et al. (1998) and Lallo and Bondan (2006), who detected Cryptosporidium in mice and dogs, respectively, there was no relation between Cryptosporidium infection and the animals gender. Also, farm sizes and water sources had no evident influence on the occurrence of infection by the protozoan.

\section{CONCLUSIONS}

There is high prevalence of protozoan infections by Cryptosporidium genus in calves raised in Campos dos Goytacazes, a county in Rio de Janeiro State, indicating that cryptosporidiosis occurs endemically in flocks. Calves raised in technically operating farms using mechanical milking, milk cooling, and water tanks showed higher infection risk by the parasite.

\section{ACKNOWLEDGMENTS}

We gratefully acknowledge Dr. Ronald Fayer, United States Department of Agriculture (USDA), for the protocols and encouragement to carry out this research, and the Núcleo de Análise Genômica Laboratory (NAG/UENF) for laboratory assistance.

\section{REFERENCES}

ALMEIDA, A.J.; MONTEIRO, M.I.; BRAGA, R.S. et al. Ocorrência de Cryptosporidium spp. em animais errantes apreendidos em Campos dos Goytacazes, RJ. J. Bras. Cienc. Anim., v.1, p.66-75, 2008.

ALMEIDA, A.J.; OLIVEIRA, F.C.; TEIXEIRA, C.S. Risco relativo da infecção por parasitos do gênero Cryptosporidium em bezerros bovinos no norte do estado do Rio de Janeiro, Brasil. Rev. Bras. Parasitol. Vet., v.17, supl.1, p.243-248, 2009.

ANGUS, K.W. Cryptosporidiosis in ruminants. In: DUBEY, J.P.; SPEER, C.A.; FAYER, R. (Eds). Cryptosporidiosis of man and animals. Boston: CRC, 1991. p.95-103.

CASTRO-HERMIDA, J.A.; ALMEIDA, A.; GONZÁLEZ-WARLETA, M. et al. Occurrence of Cryptosporidium parvum and Giardia duodenalis in healthy adult domestic ruminants. Parasitol. Res., v.101, p.1443-1448, 2007.

CHEN, X-M.; KEITHLY, J.S.; PAYA, C.V. et al. Cryptosporidiosis. N. Engl. J. Med., v.346, p.17231731, 2002.

CURRENT, W.L.; REESE, N.C.; ERNEST, J.V. et al. Human cryptosporidiosis in immunocompetent and immunodeficient persons. N. Engl. J. Med., v.308, p.1252-1255, 1983.

EDERLI, B.B.; CARVALHO, C.B.; SALES, L.G. Ocorrência da infecção por Cryptosporidium spp. em bezerros da microrregião de Campos dos Goytacazes no estado do Rio de Janeiro. Rev. Bras. Parasitol. Vet., v.13, p.45-48, 2004.

FAYER, R.; SPEECER, C.A.; DUBEY, J.P. General biology of Cryptosporidium. In: DUBEY, J.P.; SPEECER, C.A.; FAYER, R. (Eds). Cryptosporidiosis of man and animals. Boston: CRC Press, 1990. p.1-29.

FAYER, R.; MORGAN, U.M.; UPTON, S.J. Epidemiology of Cryptosporidium: transmission, detection and identification. Int. J. Parasitol., v.30, p.1305-1322, 2000. 


\section{Almeida et al.}

FAYER, R.; SANTÍN, M.; TROUT, J. et al. Prevalence of species and genotypes of Cryptosporidium found in 1-2-year-old dairy cattle in the eastern United States. Vet. Parasitol., v.135, p.105-112, 2006.

FÉRES, F.C.; LOMBARDI, A.L.; CARVALHO, M.P.P. et al. Ocorrência e caracterização molecular de Cryptosporidium em cordeiros. Arq. Bras. Med. Vet. Zootec., v.61, p.1002-1005, 2009.

FEITOSA, F.L.F.; SHIMAMURA, G.M.; ROBERTO, T. et al. Prevalência de criptosporidiose em bezerros na região de Araçatuba, estado de São Paulo, Brasil. Cienc. Rural, v.34, p.189-193, 2004.

KUCZYNSKA, E.; SHELTON, D.R. Method for detection and enumeration of Cryptosporidium parvum oocysts in feces, manures and soils. Appl. Environ. Microbiol., v.65, p.2820-2826, 1999.

LAUBACH, H.E.; BENTLEY, C.Z.; GINTER, E.L. A study of risk factors associated with the prevalence of Cryptosporidium in villages around lake Atitlan, Guatemala. Braz. J. Infect. Dis., v.8, p.319-323, 2004.

LALLO, M.A.; BONDAN, E.F. Prevalência de Cryptosporidium spp. em cães de instituições da cidade de São Paulo. Rev. Saúde Pública, v.40, p.120-125, 2006.

LIAO, S.; DU, C.; YANG, S. et al. Alteration of Cryptosporidium parvum (Apicomplexa: Eucoccidiorida) oocysts antigens following bleach treatment. Acta Protozool., v.40, p.273-279, 2001.

LUNA, S.; LILIANA, R.L.; MISAEL, C. Presencia de ooquistes de Cryptosporidium spp. en aguas superficiales en Costa Rica. Parasitol. Latinoam., v.57, p.63-65, 2002.

MACHADO, E.C.L.; STAMFORD, T.L.M.; MACHADO, E.H.L. et al. Ocorrência de oocistos de Cryptosporidium spp. em águas superficiais na região metropolitana de Recife-PE. Arq. Bras. Med. Vet. Zootec., v.61, p.1459-1462, 2009.

MADDOX-HYTTEL, C.; LANGKJAER, R.B.; ENEMARK, H.L. et al. Cryptosporidium and Giardia in different age groups of Danish cattle and pigs - ocurrence and management associated risk factors. Vet. Parasitol., v.141, p.48-59, 2006.
MALDONADO-CAMARGO, S.; ATWILL, E.R.; SALTIJERAL-OAXACA, J.A. et al. Prevalence of and risk factors for shedding of Cryptosporidium parvum in Holstein Friesian dairy calves in central Mexico. Prev. Vet. Med., v.36, p.95-107, 1998.

PARK, J.; GUK, S.; HAN, E. et al. Genotype analysis of Cryptosporidium spp. prevalent in a rural village in Hwasun-gun, Republic of Korea. Korean J. Parasitol., v.44, p.23-33, 2006.

RAMIREZ, N.E.; WARD, L.A.; SREVATSON, S. A review of the biology and epidemiology of cryptosporidiosis in humans and animals. Microbes Infect., v.6, p.773-785, 2004.

SIMMONS III, O.D.; SOBSEY, M.D.; HEANEY, C.D. et al. Concentration and detection of Cryptosporidium oocysts in surface water samples by method 1622 using ultrafiltration and capsule filtration. Appl. Environ. Microbiol., v.67, p.11231127, 2001.

SMITH, H.V.; ROSE, J.B. Waterborne cryptosporidiosis: current status. Parasitol. Today, v.14, p.14-22, 1998.

TARAZONA, R.; BLEWETT, D.A.; CARMONA, M.D. Cryptosporidium parvum infection in experimentally infected mice: infection dynamics and effect of immunossupression. Folia Parasitol., v.45, p.101-107, 1998.

VILLACORTA, I.; PEETERS, J.E.; VANOPDENBOSH, E. et al. Efficacy of halofuginone lactate against Cryptosporidium parvum in calves. Antimicrob. Agents. Chemother., v.35, p.283-287, 1991.

WADE, S.E.; MOHAMMED, H.O.; SCHAAF, S.L. Prevalence of Giardia sp., Cryptosporidium parvum and Cryptosporidium muris (C. andersoni) in 109 dairy herds in five counties of southeastern New York. Vet. Parasitol., v.93, p.1-11, 2000.

XIAO, L.; MORGAN, U.M.; FAYER, R. et al. Cryptosporidium systematics and implications for public health. Parasitol. Today, v.16, p.287-292, 2000. 